\title{
FOAMING AGENTS FOR REMOVING PROBLEM LIQUIDS FROM GAS WELLS
}

\author{
By J. L. Eakin
}

* * * * * * * * * report of investigations 6660

\section{UNITED STATES DEPARTMENT OF THE INTERIOR}

\section{BUREAU OF MINES}




\section{DISCLAIMER}

Portions of this document may be illegible in electronic image products. Images are produced from the best available original document. 
This publication has been cataloged as follows:

\section{Eakin, John L}

Foaming agents for removing problem liquids from gas wells. [Washington] U. S. Dept. of the Interior, Bureau of Mines [1965]

14 p. illus., tables. (U. S. Bureau of Mines. Report of investigations 6660)

Includes bibliography.

Based on work done in cooperation with the American Gas Association, and the State of Oklahoma.

1. Gas wells. I. Title. (Series)

TN23.U7 no. $6660 \quad 622.06173$

U. S. Dept. of the Int. Library 


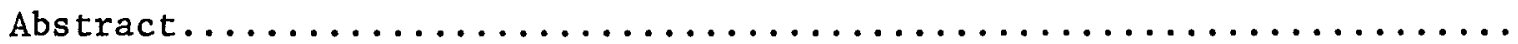

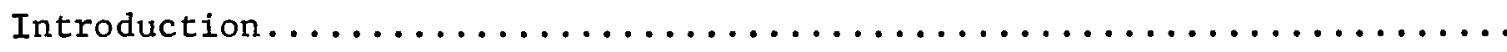

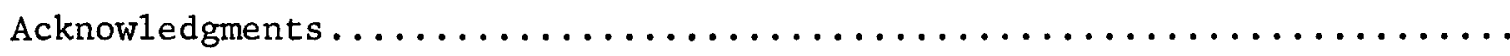

Theory.

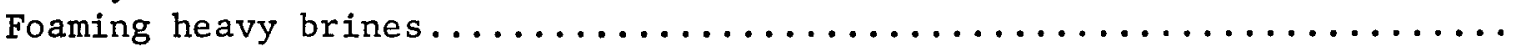

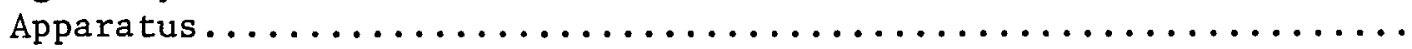

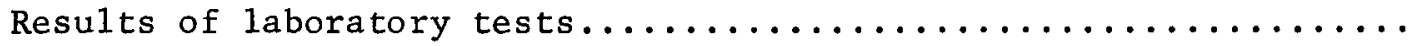

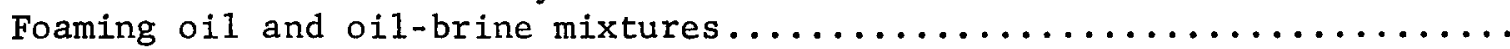

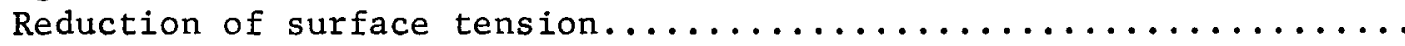

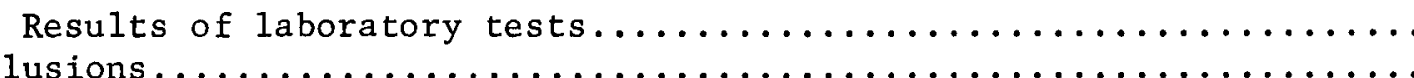

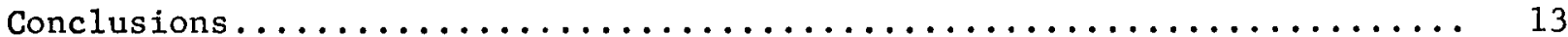

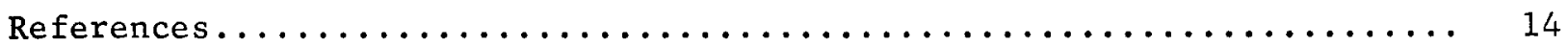

\section{ILIUSTRATIONS}

Fig.

1. Relative effectiveness of foaming ability of detergents at 0.05

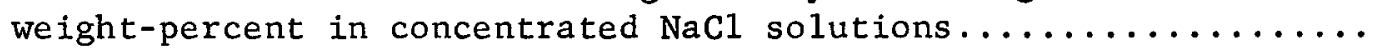

2. Effect of temperature on the foaming ability of 0.05 weight-percent

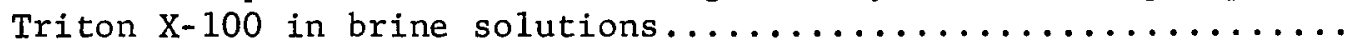

\section{TABLES}

1. Analyses of concentrated natural and commercial brines......... 4

2. Effects of mineral additives on the foaming ability of detergent-

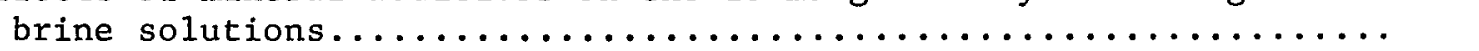

3. Composition of foaming agents tested.....................

4. Detergents for satisfactory foaming at specific test conditions..... 


\title{
FOAMING AGENTS FOR REMOVING PROBLEM LIQUIDS FROM GAS WELLS
}

\author{
by \\ J. L. Eakin ${ }^{1}$
}

\begin{abstract}
The Bureau of Mines determined agents that are effective in foaming heavy brines and oil from gas wells in severe concentrations of sodium chloride, in severe concentrations of calcium chloride, or in moderate oil-brine mixtures. Dynamic foam tests were designed to select the more effective foaming agents.

Numerous foaming agents were tested in concentrated simulated brines, in oilfield brines having varied concentrations of ions, in heavy natural brines, and in a commercial brine generally used as a reservoir pressure-balancing fluid. Several agents were detected that could perform efficiently in the field under the most severe saline conditions. Agents that promote foaming in oil-brine mixtures were also determined.
\end{abstract}

\section{INTRODUCTION}

The work described in this report was part of the Bureau of Mines overall program on the use of detergents to improve productivity of natural gas wells by removing liquids and solids from the wellbores. It supplements earlier research. (2) ${ }^{2}$ to establish guidelines for determining the applicability of foam treatments in the field. A specific objective was to evaluate by previously standardized laboratory and field methods new foaming agents developed for use in we11s to remove heavy brine (brine, with higher than average total solids), oil, and oil-brine mixtures. This research was performed both to assist in removing brine from problem wells and to assist in reviving gas production from new and reconditioned wells that showed decreased production. Wells considered here are those with decreased productivity as a result of formation damage from mud filtrate and water or those damaged wells that had the gas flow "balanced" with heavy commercial brines during completion or servicing.

\footnotetext{
${ }^{1}$ Project leader, Bartlesville Petroleum Research Center, Bureau of Mines, Bartlesville, Okla.

2 Underscored numbers in parentheses refer to items in the list of references at the end of this report.
}

Work on manuscript completed November 1964. 


\section{ACKNOWLEDGMENTS}

This work was done by the Bureau of Mines under cooperative agreements with the American Gas Association and with the State of Oklahoma. The author expresses appreciation to the manufacturers that supplied foaming agents used in the tests.

\section{THEORY}

The accumulation of concentrated brine and liquid hydrocarbons makes it difficult for gas well operators to clean wellbores by the foam method patented by Dunning and Walker (4). The foaming and liquid-carrying ability of most commercial detergents is severely dampened in mixtures of brines and liquid hydrocarbons and in oilfield and gasfield brines that have high concentrations of sodium and/or calcium chloride.

When properly mixed with liquids in the wellbore and agitated by a sma11 amount of gas from the producing formation, foaming agents normally form a light foam column. This lightened column can be lifted from the well by gas pressure insufficient to lift an equal column of water. However, in the present investigation many detergents failed to foam efficiently in brines as the sodium chloride content approached the saturation point and in brines having high concentrations of calcium; no detergent was applicable to a broad range of crude oil-brine mixtures.

Recently, the use of foaming agents in various phases of oil and gas operations has been emphasized considerably. Detergents of all types have been used extensively during cleanout operations in oil- and gas-production wells, in water-input we1ls, in connection with acidizing wells, and in other stimulative treatments $(\underline{6}, \underline{8})$. A choice of detergents is available commercially to perform practically any assignment.

The detergents and foaming agents available for testing in commercial applications represent a wide variety of chemical compositions and properties. Johansen, Dunning, and Beaty (ㄱ) divided detergents into three types (cationic, anionic, and nonionic) according to their ionization products. If the oilsoluble part of the molecule forms a positive ion, the detergent is classed as cationic; however, if the oil-soluble ions are negatively charged the detergent is anionic. Amphoteric detergents contain cationic and anionic groups and are either cationic or anionic under acidic or basic conditions, respectively. True amphoterism occurs in a system when the right amount of acid is added to balance the cationic and anionic properties. At this point a balanced ion, often called a zwitterion, is formed; such ions are both positive and negative at the same time. Detergents that do not ionize but owe their solubility in water to the polar group in the hydrophilic (water-loving) side chain are classed as nonionic. Built or commercially formulated detergents commonly contain inorganic substances such as carbonates, borax, and polyphosphates, which enhance the effectiveness of the detergent.

A modern adaptation of the foaming action of detergents is used to assist in lifting water, brine, and drill-cuttings from wells being drilled with 
either air or gas. Detergents: are used as additives in drilling mud to reduce friction and in cleanout operations on gas wells "drowned" by brine, oil, or mud. Detergents are also effective for removing water blocks from the formation around gas wells ( $\underline{5})$, as shown by the Bureau of Mines in a recently developed alcohol-surfactant treatment.

\section{FOAMING HEAVY BRINES}

Because balancing the reservoir pressure of individual gas wells with fresh water causes clay swelling and other detrimental effects, more operators are using weighted commercial brines as balancing fluids during these operations. Concentrated commercial brines vary in their mineral content, depending upon the source bed; however, they are principally sodium chloride. Usually less than 1 percent of the total dissolved solids is represented by the combined calcium chloride and bicarbonates.

Numerous reports have been published on brine analyses (9-11). Differences in mineral content, even in trace quantities, aid in identifying the sources of particular brines. These reports also show that gasfield brines generally contain higher concentrations of dissolved salts than oilfield brines. High mineral concentrations in the reservoir and wellbore are probably caused by the evaporative action of the gas removing the formation water. It is not uncommon for gas wells to produce only periodically and at relatively high rates. In wells from which only small amounts of formation water are produced, water tends to evaporate at the sand face, probably leaving either concentrated brine: or an accumulation of recrystallized salt in the wellbore. Greater depths of gas. wells, with accompanying increased reservoir temperatures and pressures, also probably enhance the concentration in brines of gas-productive formations and wellbores.

Fortunately. the problem of lifting heavy natural brine from gas wells is not widespread. Isolated wells produce heavy brine in areas of the Texas Panhandle, west Texas, Michigan, and Ohio.

Because many gasfield brines and balancing" fluids are highly concentrated with:salts, removing them from drowned gas wells by the foam method is difficult. Selecting effective foaming agents for the current study was simplified to some extent through the cooperation of various detergent or foaming-agent manufacturers. Several suppliers of detergents suggested better foaming agents that appeared to be least affected by increased salinity. Other manufacturers compounded agents specially designed to foam in heavy brines. Unfortunately, many detergents with good static foam characteristics are not particularly efficient liquid carriers. In this application the critical measure of effectiveness is the amount of liquid held in the foam and carried out of the we11.

\section{Apparatus}

Evaluation tests were made using the Bureau of Mines standard dynamic foam test apparatus (2). To $500 \mathrm{ml}$ of the test solution, foaming agents are added in concentrations of 0.05 weight-percent active ingredient. Briefly, 
the apparatus consists of a Pyrex ${ }^{3}$ glass tube column with standard tapered joints sealed to the top and bottom. A plastic hose attached to a cap on the top joint directs the effluent to a graduated cylinder. A Pyrex funnel with a sealed-in, medium-fritted-glass disk attached to the bottom standard tapered joint of the column serves as an aerator. The system air supply is regulated with a Fisher float-type, laboratory flowmeter and is maintained manually at a flow rate of one-half liter per minute. The volume of water measured in the graduated cylinder is recorded after 20 minutes. Except for duplicate runs made with natural brines, the results of all tests are given as the average of at least four runs. Maximum variation between results from identical tests is plus or minus about 5 percent.

\section{Results of Laboratory Tests}

Numerous detergents that are effective for foaming either fresh water or light brines rapidly lose their ability to foam brines that have a higher mineral content. Normally, to be effective in field operations, a detergent should have a liquid removal capactiy or "carryover" of approximately $300 \mathrm{~m} 1$ from the foam column to the graduated cylinder after 20 minutes:

Table 1 presents the results of mineral analyses of the concentrated natural and commercial brines used during this series of tests. The brines were selected from wells in which the concentration of dissolved salts in the water had prohibited the successful field application of the foam method. Natural brines were supplied by companies operating wells in Michigan and the Texas Panhandle. A sample of commercial brine was furnished by a supplier in the Odessa, Tex., area. A sample of Bartlesville sandstone brine was used as a standard test brine in which to concentrate various ions. Morton's medium salt, a water softener, was used to prepare solutions of simulated brines at various concentrations: The mineral content of Morton's medium salt was measured in parts per million as follows: Calcium chloride $\left(\mathrm{CaC}_{2}\right), 4,000$; sodium chloride $(\mathrm{NaCl}), 995,020$; and bicarbonate $\left(\mathrm{HCO}_{3}^{-}\right), 980$.

TABLE 1. - Analyses of concentrated natura1 and commercial brines

\begin{tabular}{|c|c|c|c|c|c|c|}
\hline & \multicolumn{3}{|c|}{ Michigan brines } & \multicolumn{2}{|c|}{ Texas brines } & \multirow{2}{*}{$\begin{array}{c}\text { Oklahoma } \\
\begin{array}{c}\text { Bartlesville } \\
\text { brine }\end{array}\end{array}$} \\
\hline & $\begin{array}{c}\text { Salina } \\
1\end{array}$ & $\begin{array}{c}\text { Salina } \\
2 \\
\end{array}$ & Stray & \begin{tabular}{|l} 
Kryder- \\
Winfield \\
\end{tabular} & $\begin{array}{l}\text { West Texas } \\
\text { commerciai }\end{array}$ & \\
\hline Specific gravity..... & 1.220 & 1.218 & 1.218 & 1.215 & 1.208 & 1.087 \\
\hline $\begin{array}{l}\text { nalysis, mg/liter: } \\
\text { Barium }\left(\mathrm{Ba}^{++}\right) \ldots \ldots \\
\text { Calcium }\left(\mathrm{Ca}^{++}\right) \ldots \ldots \\
\text { Magnesium }\left(\mathrm{Mg}^{++}\right) \ldots \\
\text { Sodium }\left(\mathrm{Na}^{+}\right) \ldots \ldots \\
\text { Bicarbonate }\left(\mathrm{HCO}_{3}\right) \\
\text { Sulfate }\left(\mathrm{SO}_{4}\right) \ldots \ldots \\
\text { Chloride }\left(\mathrm{C} 1^{-}\right) \ldots \ldots \\
\text { Total solids } \ldots .\end{array}$ & $\begin{array}{r}280 \\
41,800 \\
5,700 \\
68,200 \\
70 \\
1,120 \\
195,000 \\
312,170 \\
\end{array}$ & $\begin{array}{r}900 \\
38,000 \\
5,400 \\
71,900 \\
70 \\
1,450 \\
193,200 \\
310,920\end{array}$ & $\begin{array}{r}0 \\
29,200 \\
6,800 \\
81,800 \\
70 \\
1,130 \\
196,800 \\
315,800\end{array}$ & $\begin{array}{r}0 \\
12,260 \\
12,700 \\
86,900 \\
40 \\
760 \\
195,000 \\
308,660 \\
\end{array}$ & $\begin{array}{r}1,840 \\
1,070 \\
118,600 \\
160 \\
4,160 \\
186,150 \\
311,980\end{array}$ & $\begin{array}{r}0 \\
8,620 \\
940 \\
39,000 \\
90 \\
290 \\
77,800 \\
126,740\end{array}$ \\
\hline
\end{tabular}

\footnotetext{
${ }^{3}$ Reference to specific brands is made for identification only and does not imply endorsement by the Bureau of Mines.
} 
Selected detergents were tested in distilled water at a concentration of 0.05 weight-percent active ingredient, but only those that performed most satisfactorily during the series of tests were listed in table 2 . Generally, the efficiency of foaming or water-carrying capacity of most detergents decreases with increased salinity. Many detergents failed and were eliminated as the sodium chloride content approached 20 percent. Data listed in this table indicate the most successful foaming agents tested and the comparative volumes of liquid carryover with sodium chloride concentrations ranging from 0 to 25 weight-percent near the saturation points of the liquids.

The results of the second series of tests, 1 isted in the middle portion of table 2, show the effect of altering Bartlesville brine on the foaming tendency of some detergents. A series of tests were run on numerous detergents at concentrations of 0.05 weight-percent active ingredient in oilfield brine in which the content of calcium, magnesium, bicarbonate, carbonate, and su1fate were increased to the maximum values usually found in natural brines. Calcium appears to have the most significant effect on foaming. From the results of auxiliary tests, not presented in table 2 , it was found that in general brines containing calcium adversely affect the foaming ability of Triton X-102, Triton X-165, Deriphat 170-C and Howco suds.

Results reported in the lower part of table 2 indicate that only a few of the dozen detergents are efficient foamers of these concentrated brines. A11 agents 1 isted in the table perform efficiently under the severe conditions of changed mineral content. However, the proof of all testing comes only

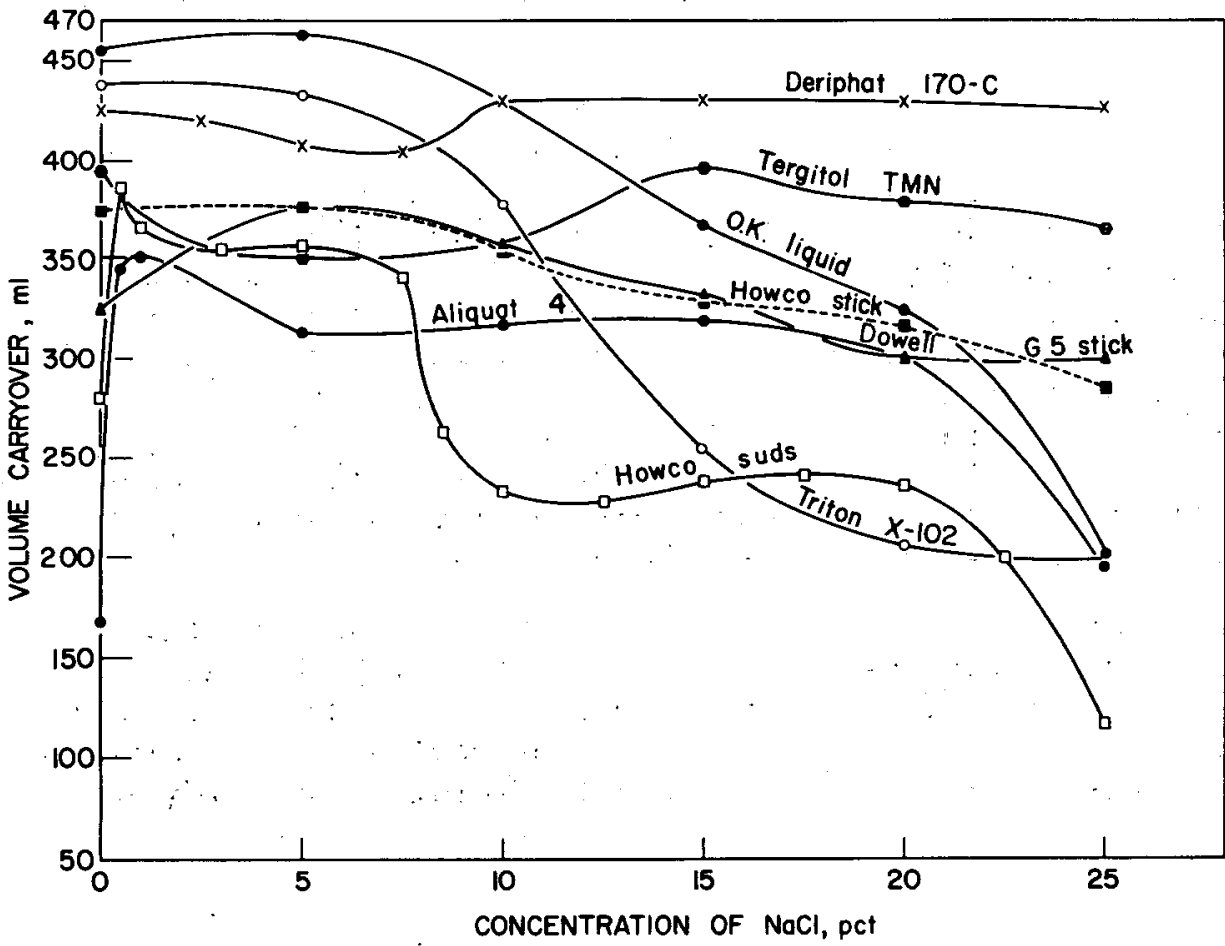

FIGURE 1. - Relative Effectiveness of Foaming Ability of Detergents at 0.05 Weight-Percent in Concentrated $\mathrm{NaCl}$ Solutions. when the foaming agents perform efficiently under field conditions.

Figure 1 shows the relative foaming ability the detergents te tested at 0.05 weight-percent active ingredient. The top curve shows that Deriphat 170-C foams exceptionally well in highly concentrated sodium chloride solutions. However, succeeding tests showed this agent was unsuccess ful in foaming brines containing calcium ions. Tergitol TMN, Dowe11 G5 stick, 


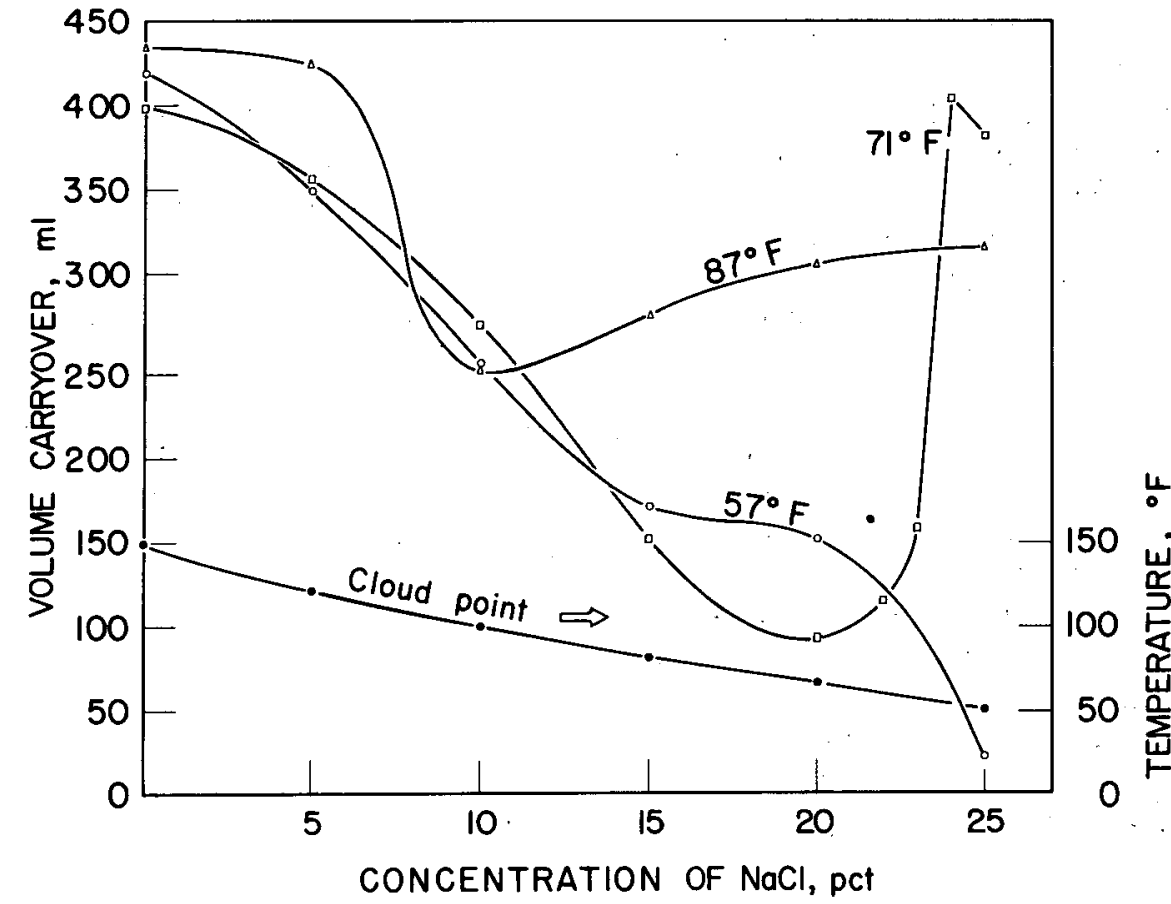

FIGURE 2. - Effect of Temperature on the Foaming Ability of 0.05 Weight-Percent Triton X-100 in Brine Solutions. and Howco stick were relatively unaffected by increased salinity. These tests indicated that the foaming efficiency of many proven detergents is depressed in concentrated brines.

However, these results do not reflect upon the detergents' ability to foam in normal brines, in air and gas drilling, and in other applications for which they were originally developed.

The foaming tendency of both Aliquat 4 and Howco suds was noticeably increased by the addition of as little as 0.5 weight-percent sodium chloride. This feature results from the agents being formulated especially for foaming in electrolytes.

The foaming characteristics of three nonionic agents 1 isted in table 2 did not follow the general pattern because of an anomaly that occurred when approaching and passing the cloud point. The cloud point is the temperature at which sufficient detergent precipitates to cloud the test solution. Examples of the effects of the cloud point may be noted from data tabulated for Dowe11 G2, Tergito1 TMN, and Triton X-100. A11 solutions made up with Tergitol TMN that were more saline than the initial solution with distilled water. were beyond the cloud point, and efficient foaming resulted. The cloud point for an aqueous solution of Triton $X-100$ was reached at room temperature at about 15 percent $\mathrm{NaCl}$; at concentrations above 23 percent $\mathrm{NaCl}$, the agent foamed remarkably wel1. Dowe 11 G2 and Triton X-100 follow similar patterns with respect to the effect on foaming brought about by clouding of the test solutions. Special tests were performed with these two agents.

Figure 2 shows an example of the effect of a moderate change in temperature on the foaming ability of 0.05 weight-percent Triton X-100 in sodium chloride solutions. This phenomenon is of particular interest to manufacturers and research chemists. The tiny particles of detergent coming out of solution apparently have a relatively high surface viscosity, affording more efficient foaming action than that obtained from the original detergent. Nonionic detergents normally drop out of solution and produce low foaming when exposed to higher temperatures and increased $\mathrm{NaCl}$ concentrations. These unexpected results indicate nonionic detergents may perform satisfactorily beyond their cloud points in wells having high bottom-hole temperatures. 
TABLE 2. - Effects of mineral additives on the foaming ability of detergent-brine solutions ${ }^{1}$

\begin{tabular}{|c|c|c|c|c|c|c|c|c|c|c|c|c|}
\hline \multirow{4}{*}{$\because$} & \multicolumn{3}{|c|}{ Cationic detergents } & \multicolumn{2}{|c|}{ Anionic detergents } & \multicolumn{7}{|c|}{ Nonionic detergetns } \\
\hline & \multicolumn{2}{|c|}{ General Mills } & \multirow{3}{*}{$\begin{array}{l}\text { Armour } \\
\text { Armomist }\end{array}$} & \multirow{3}{*}{$\begin{array}{l}\text { American } \\
\text { Cyanamid } \\
\text { RC-250 }\end{array}$} & \multirow{3}{*}{$\begin{array}{l}\text { Antara } \\
\text { Gafac } \\
\text { RE } 610\end{array}$} & \multirow{2}{*}{\multicolumn{2}{|c|}{ Dowe 11}} & \multirow{3}{*}{\begin{tabular}{|l|} 
Antara \\
Gafen \\
FA-5
\end{tabular}} & \multirow{3}{*}{$\begin{array}{l}\text { Howco } \\
\text { stick }\end{array}$} & \multirow{3}{*}{\begin{tabular}{|c|} 
Union \\
Carbide \\
Tergitol \\
TMN
\end{tabular}} & \multicolumn{2}{|c|}{ Rohm \& Haas } \\
\hline & Alifoam & Aliquat & & & & & & & & & \multirow{2}{*}{$\begin{array}{r}\text { Triton } \\
\mathrm{X}-100\end{array}$} & \multirow{2}{*}{$\begin{array}{r}\text { Triton } \\
\mathrm{X}-114\end{array}$} \\
\hline & & & & & & G2 & G5 & & & & & \\
\hline \multicolumn{13}{|c|}{ Foaming } \\
\hline \multicolumn{13}{|c|}{-} \\
\hline $0 \ldots$ & 403 & 168 & 262 & 379 & 384 & 404 & 325 & 368 & 374 & 395 & 399 & 400 \\
\hline$\therefore \therefore \ldots$ & 458 & 313 & 256 & 362 & 414 & 306 & 375 & 393 & 376 & 351 & 356 & 385 \\
\hline $10 \ldots$ & 464 & 317 & 254 & 313 & 374 & 165 & 358 & 374 & 354 & 357 & 279 & 320 \\
\hline $15 \ldots$ & 366 & 319 & 276 & 275 & 378 & 205 & 332 & 344 & 328 & 397 & 152 & 310 \\
\hline $20 \ldots$ & 238 & 300 & 243 & 268 & 370 & 378 & 300 & 310 & 316 & 379 & 93 & 255 \\
\hline $25 \ldots \ldots \ldots \ldots \ldots$ & 244 & 195 & 222 & 253 & 281 & 305 & 300 & 276 & 285 & 365 & 381 & 132 \\
\hline
\end{tabular}

Foaming of Bartlesville. Brine Solutions with Selected Additives, ml

\begin{tabular}{|c|c|c|c|c|c|c|c|c|c|c|c|c|}
\hline \multicolumn{13}{|l|}{ Additives, percent: } \\
\hline $0 \ldots \ldots \ldots$ & 366 & 370 & 393 & 350 & 353 & 225 & 352 & 390 & 354 & 384 & 264 & 378 \\
\hline $2 \mathrm{Ca}^{++} \ldots \ldots \ldots$ & 276 & 361 & 357 & 351 & 291 & 176 & 337 & 388 & 324 & 368 & 222 & 415 \\
\hline $3 \mathrm{Ca}^{++} \ldots \ldots \ldots \ldots$ & 256 & 326 & 351 & 260 & 293 & 294 & 335 & 354 & 331 & 376 & 193 & 428 \\
\hline $4 \mathrm{Ca}^{++} \ldots \ldots \ldots$ & 245 & 331 & 320 & 255 & 200 & 336 & 353 & 320 & 294 & 389 & 180 & 422 \\
\hline $0.1 \mathrm{HCO}_{3} \ldots \ldots \ldots$ & 388 & 408 & 392 & 274 & 318 & 233 & 356 & 420 & 417 & 368 & 265 & 393 \\
\hline $0.003 \mathrm{CO}_{3}=\ldots \ldots$ & 392 & 407 & 390 & 312 & 324 & 260 & 365 & 418 & 412 & 370 & 284 & 424 \\
\hline $0.255 \mathrm{SO}_{4}=\ldots \ldots \ldots$ & 372 & 383 & 326 & 319 & 327 & 204 & 367 & 414 & 400 & 344 & 277 & 400 \\
\hline $1.315 \mathrm{Mg}^{++} \ldots \ldots \ldots$ & 295 & 392 & 314 & 344 & 397 & 183 & 351 & 385 & 303 & 377 & 175 & 416 \\
\hline \multicolumn{13}{|c|}{ Foaming of Concentrated Natural } \\
\hline Salina $1 \ldots \ldots \ldots$ & 275 & 244 & 255 & 125 & 168 & 328 & 305 & 243 & 262 & 351 & 228 & 189 \\
\hline Salina $2 \ldots \ldots \ldots$ & 274 & 237 & 241 & 151 & 202 & 390 & 305 & 211 & 289 & 305 & 225 & 184 \\
\hline Stray............ & 82 & 160 & 166 & 235 & 114 & 345 & 331 & 218 & 228 & 324 & 345 & 283 \\
\hline Kryder-Winfield.. & 251 & 240 & 249 & - & - & 367 & 113 & 260 & 244 & 349 & 346 & 205 \\
\hline \multicolumn{13}{|l|}{ West Texas } \\
\hline Commercial. & 250 & 123 & 125 & 182 & 249 & 187 & 277 & 233 & 135 & 274 & 354 & 161 \\
\hline
\end{tabular}

${ }^{1}$ Detergent concentration, 0.05 weight-percent active ingredient; figures in milliliters represent liquid removed from foam column in 20 minutes.

${ }^{2}$ Average of duplicate tests. 
The available information on chemical compositions of all agents studied is summarized in table 3 .

\section{FOAMING OIL AND OIL-BRINE MIXTURES}

Gas wells often suffer loss in production rate because of the gradual accumulation of crude oil, brine, or a combination of these liquids. Existing reservoir energy is sometimes incapable of lifting these liquids to the surface. After numerous requests from industry for information, means were sought to apply the foam method to this problem.

Considering the complexities and number of well conditions encountered in foaming crude oil and oil-brine mixtures, only minor success could be expected in developing effective methods and agents for use over a broad range of field conditions. A few of the variable conditions are pressure, volume and type of well fluid, completion with respect to wellbore diameter and size of tubular goods, and changing surface phenomena. The surface forces are further complicated by adding detergents to the systems. The large number of books and papers on surface chemistry testifies to a considerable understanding of surface forces and behavior. However; the problem of foaming oil. and oil-brine mixtures from wells is not urgent enough to support either basic studies involving the general categories of surface chemistry and physics or a pròlonged applied research effort.

Although the extensive field test program on removing brine by the foam method revealed that most oils and oil-brine mixtures resisted foaming by ordinary detergents, some foaming agents were moderately effective. Concurrently, several manufacturers of detergents developed and tested improved foaming agents. Results from earlier Bureau of Mines research (1-2) and industry research ( 3 ) indicated that, although the foaming properties of some cationic fatty quaternaries differed widely, they were effective at very low concentrations. The low-molecular-weight fatty quaternaries were most effective for foaming strong acids, heavy brines, and mixtures of oil and brine. The higher-molecular-weight quaternaries were effective in brines and straight oil. Foaming is dependent upon an increase in surface activity and its relationship to the film foaming properties of the solution being tested. Some crude oils foam readily owing to the presence of natural surface-active materials; one such class of compounds is naphthenic acids. As reported earlier, some of the quaternary ammonium compounds have been effective in foaming a variety of crude oils. However, no universal oil-foaming agent has been made available.

\section{Reduction of Surface Tension}

It appeared logical to investigate the problem of foaming mixtures of crude oil and brine by reducing the surface tension of the brine phase with an agent that would produce relatively stable foam and tolerate the presence of oil. Foam formed by most nonionic detergents is usually broken by the oil phase of the system. The surface tension of the oil phase, being low, was found most difficult to reduce significantly. Foaming agents that were moderately effective in crude oil failed in tests with oil-brine mixtures. In the more successful tests the oil phase was lifted as a film interspersed through the foam. 
TABLE 3. - Composition of foaming agents tested

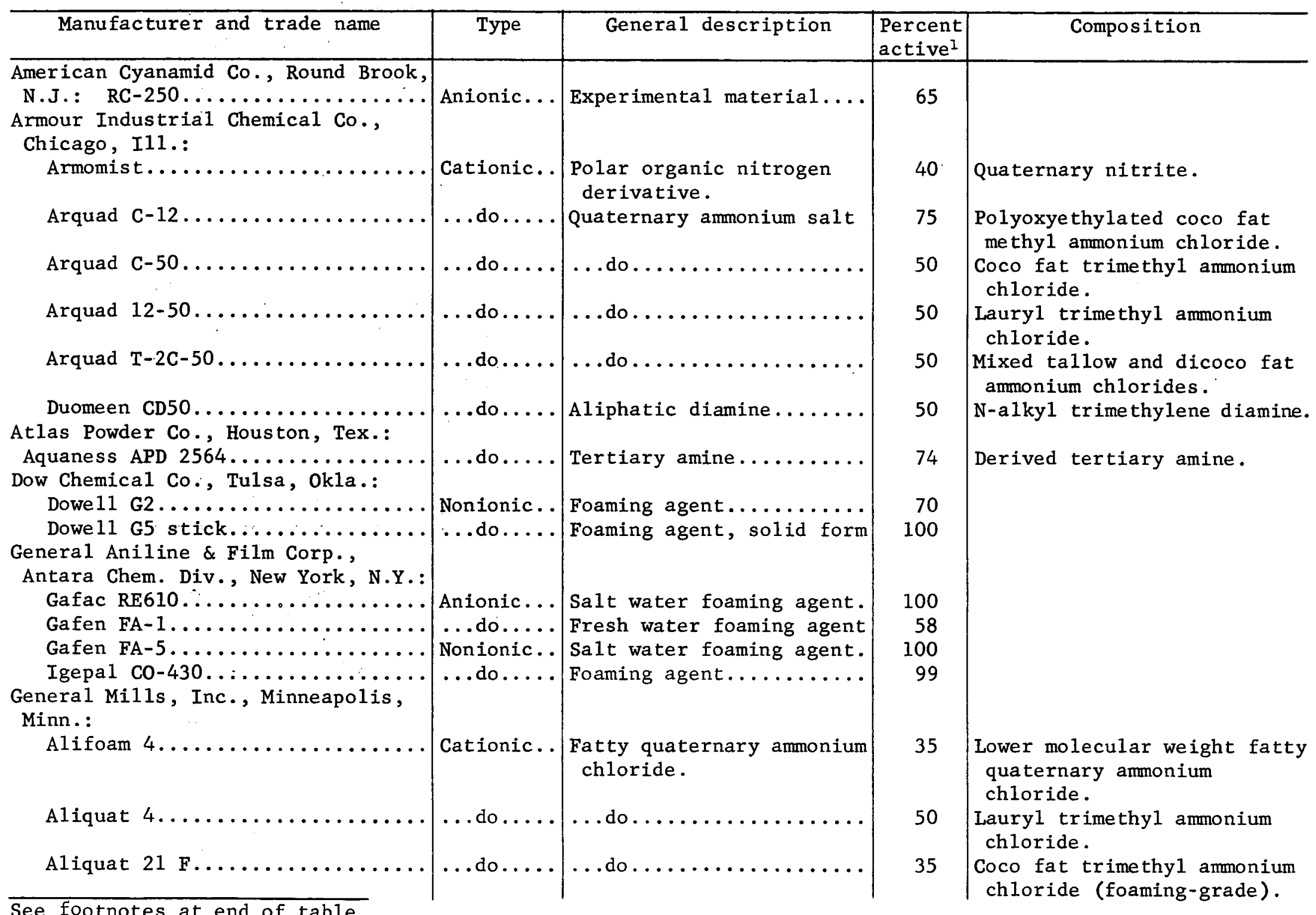


TABLE 3. - Composition of foaming agents tested--Continued

\begin{tabular}{|c|c|c|c|c|}
\hline Manufacturer and trade name & Type & Genera1 description & \begin{tabular}{|l|} 
Percent \\
active
\end{tabular} & Composition \\
\hline $\begin{array}{l}\text { General Mills, Inc., Minneapolis, } \\
\text { Minn.:--continued }\end{array}$ & & & & \\
\hline Aliquat 400 . & Cationic.. & $\begin{array}{l}\text { Fatty quaternary ammonium } \\
\text { chloride. }\end{array}$ & 50 & $\begin{array}{l}\text { Mixed mono tallow-dicoco } \\
\text { fat quaternary ammonium } \\
\text { chlorides. }\end{array}$ \\
\hline Deriphat $170-c \ldots \ldots \ldots \ldots$ & Amphoteric ${ }^{2}$ & Fatty amphoteric. & 50 & $\begin{array}{l}N \text {-lauryl } \beta \text {-aminopropionic } \\
\text { acid. }\end{array}$ \\
\hline 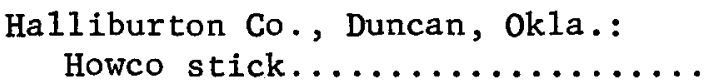 & Nonionic.. & Foaming agent, solid form & 84 & \\
\hline $\begin{array}{l}\text { Howco suds.......................... } \\
\text { Jefferson Chemical co.. Inc. }\end{array}$ & ..do..... & 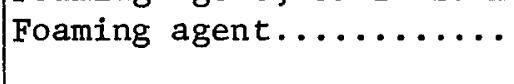 & 65 & \\
\hline Houston, Tex.: Sulfonic $\mathrm{N}-150 \ldots$ & ...do..... & $\begin{array}{l}\text { Polyoxye thylated a1kyl } \\
\text { phenol. }\end{array}$ & 100 & $\begin{array}{l}\text { Polyoxye thylated nonylphenol } \\
\text { (150 oxye thylene units). }\end{array}$ \\
\hline $\begin{array}{l}\text { Minnesota Mining \& Manufacturing } \\
\text { Co., St. Paul, Minn.: 3M L-1083.. } \\
\text { Procter \& Gamble Co., Cincinnati, } \\
\text { Ohio: }\end{array}$ & Amphoteric ${ }^{2}$ & Flurochemical surfactant. & 100 & \\
\hline $0 . \mathrm{K}$. 1iquid.... & Anionic... & Laury1 sulfate.......... & 70 & $\begin{array}{l}\text { Ammonium lauryl sulfate } \\
\text { plus amide builder. }\end{array}$ \\
\hline$\ldots \ldots \ldots \ldots$ & Noni & imental material.... & 23 & Foaming agent No. 29 . \\
\hline$P \& G \quad T-3$ & hic & $\ldots d$ & 32 & \\
\hline$P \& G \quad T-5 \ldots$ & Nonionic.. & ...do. . & 27 & \\
\hline $\begin{array}{c}\text { Rohm \& Haas Co., Philadelphia, Pa.: } \\
\text { Hyamine } 1622 \ldots \ldots \ldots \ldots \ldots \ldots \ldots\end{array}$ & Cationic.. & $\begin{array}{l}\text { Quaternary ammonium } \\
\text { chloride. }\end{array}$ & 100 & $\begin{array}{l}\text { Diiosbutyl phenoxyethyoxy. } \\
\text { ethyl dimethyl benzyl } \\
\text { ammonium chloride. }\end{array}$ \\
\hline Triton QS-15 & Amphoter ic & $\begin{array}{l}\text { Amphoteric oxyethylated } \\
\text { sodium salt. }\end{array}$ & 100 & $\begin{array}{l}\text { Polyoxyethylated sodium salt } \\
\text { or sulfated ethoxy product. }\end{array}$ \\
\hline Triton $X$ & Noni & Polyoxye thylated phenol.. & 100 & Polyoxye thylated octylphenol. \\
\hline Triton X-100 & ...d & $\ldots$ do............ & 100 & Do. \\
\hline Triton X-102. & $\ldots \mathrm{dc}$ & ...do............... & 100 & Do. \\
\hline Triton X-114 & ...do & $\ldots$ do $\ldots \ldots \ldots \ldots \ldots \ldots \ldots$ & 100 & Do. \\
\hline Triton $X-1$ & ...do & $\ldots$ do...... & 70 & Do. \\
\hline $\begin{array}{l}\text { Union Carbide Corp., } \\
\text { N.Y.: Tergitol TMN... }\end{array}$ & $\ldots d$ & Polyoxye thylated nonanol. & 90 & Trimethyl nonanol. \\
\hline
\end{tabular}

N.Y.: Tergito1 TMN..................... Polyoxyethylated nonanol. 90 Trimethyl nonano1.

${ }^{2}$ Cationic or anionic under acidic or basic conditions, respectively. 
Mixtures of brine and crude oil present difficult problems in foaming; however, the substantial research has resulted in agents that foam a few selected samples of crude oil and mixtures of some crude oils and brine. Although completely satisfactory materials and methods that can be applied to a wide range of field conditions have not been developed, this fact emphasizes the importance of testing specific well liquids.

\section{Results of Laboratory Tests}

Hundreds of commercial and experimental detergents and other chemicals were tested by a simple test tube shake test from which the better foaming agents were selected for further testing. Although these foaming agents did not equal the performance of the common foaming agents for water, the results of some of the more successful tests performed in the standard dynamic foam apparatus are shown in table 4. Satisfactory foaming was induced under specific test conditions by those agents listed in the table. Satisfactory in this application represents a liquid carryover of more than $250 \mathrm{ml}$ from a possible volume of $500 \mathrm{~m} 1$ of test solution in 20 minutes.

TABLE 4. - Detergents for satisfactory foaming at specific test conditions

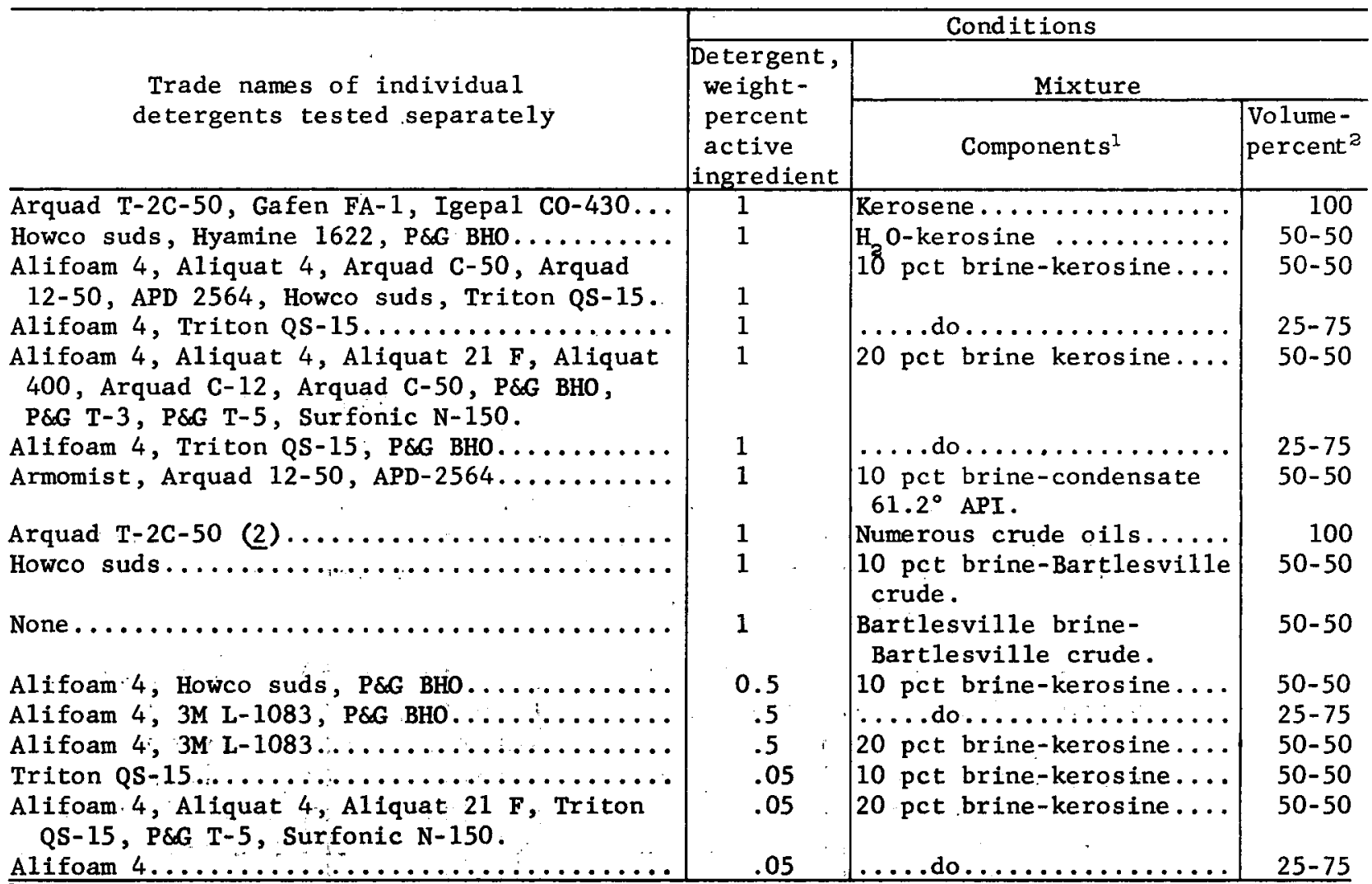

${ }^{1}$ Artificial brine used in mixtures unless otherwise identified.

2 Figures key to components column; for example for 10 percent brine-kerosine, and $25-75$ volume-percent, the mixture would contain 25 volume-percent brine and 75 volume-percent kerosine.

Table 4 records 10 foaming agents that may be expected to induce satisfactory foaming at 1 weight-percent active ingredient in 50-50 mixtures of 20 percent brine and kerosine. However, on1y 6 agents were effective at 0.05 weight-percent active ingredient in similar mixtures. The manufacturers and chemical compositions of the additional foaming agents studied are summarized in table 3. 
other chemicals and materials tested for their foam-producing characteristics included emulsifying agents and viscosity building materials such as guar gums, finely divided silica, and other powdery substances. These were tested in the foam column at 1 weight-percent in oil and in oil-brine mixtures and by adding 1 weight-percent active ingredient of selected detergents. Similarly, some of the fatty oils, including some spreading oils, were tested with few promising results. The vegetable and animal oils tested were cottonseed, corn, coconut, banana, turpentine, olive, castor, codliver and neat's-foot oils. In addition, the testing of a variety of acids, solvents, industrial soaps, cleaning compounds, patented oil foamers, and other chemicals at 1 weight-percent in the foam column provided few encouraging results.

For example, four good water-foaming agents failed to foam in kerosine at 1 weight-percent active ingredient. Further tests with these agents failed at 0.5 weight-percent active ingredient and 0.5 weight-percent naphthenic acid in 50-50 mixtures of kerosine and 10 percent brine. A 1-percent concentration of naphthenic acid in a sample of $42.1^{\circ}$ API gravity crude oil induced moderate foaming from which liquid carryover of $160 \mathrm{ml}$ was produced after 20 minutes. Numerous foaming agents were tested at 1 weight-percent active ingredient in $34^{\circ}$ API gravity Bartlesville sand crude oil. All agents failed; however, Triton X-15 and Duomeen CD50 each induced moderate foaming at about $130-\mathrm{ml}$ carryover. In, another series of tests. involving 10 of the better foaming agents at 1 weight-percent active ingredient in 50-50 mixtures of Bartlesville sand crude oil and 10 percent brine; each agent induced some foaming. The best results were with Howco suds, which produced a carryover of $275 \mathrm{ml}$.

Some increased foaming was induced in a crude oil-brine-detergent system by adding finely divided silica. The height of foam extended only to the top of the foam column when testing a 1 percent active ingredient of Aliquat 4 in a 50-50 mixture of Bartlesville sand brine and crude oil. When $400 \mathrm{ml}$ of CabO-Sil (silica powder) was included in identical subsequent tests; the average carryover of liquid was improved slightly to $197 \mathrm{ml}$. However, this was too low to expect efficient foaming in the field.

The agent $\mathrm{BHO}$ at 1 weight-percent active ingredient in 50-50 mixtures of Bartlesville brine and crude oil produced an average carryover of $221 \mathrm{ml}$. This volume of carryover was depressed during eight tests where 1 weightpercent of various vegetable and animal oil was added and minor increases resulted from the addition of banana oil and olive oil. The volume of carryover from the various crude oil-brine-detergent fatty oil mixtiures were depressed by including neat's-foot oil, linseed oil, castor oil, Mazola corn oil, turpentine, peanut oil, coconut oil, and codliver oil. The average carryover of $221 \mathrm{ml}$ was increased only slightly to 229 and $234 \mathrm{ml}$ by adding banana oil and olive oil, respectively. These minor increases are not sig-. nificant because they are within the experimental error of the test results. 


\section{CONCLUSIONS}

The laboratory test results indicate that some detergents can foam brines under severe saline conditions. Detergents in the cationic and anionic groups performed reasonably well through the first two series of tests, as shown by results recorded in table 2. A few of the nonionic agents performed reasonably well throughout the entire series, and only these agents might be expected to perform well under field conditions. In selecting a detergent to foam heavy brine from a gas well, a few simple preliminary tests should be made. Selection can be simplified by vigorously shaking bottles containing samples of brine from the well with carefully selected detergents and observing their relative foaming tendency.

Although only a few foaming agents effectively foamed crude oil and oilbrine mixtures, the resulting data indicate the conditions under which the better foamers produce satisfactorily. Light liquid hydrocarbons and brine in approximately equal amounts may be removed from wells by the foam method using one of the agents listed. Wells that have impaired gas production from the accumulation of crude oil only would be difficult to revive by using any of the surfactants now available. However, attempts by commercial companies to develop improved foaming agents are continuing. 


\section{REFERENCES}

1. Dunning, H. N., J. L. Eakin, J. L. Reinhardt, and C. J. Walker. Foaming Agents: Cure for Water Logged Gas We11s. Petro1. Eng., v. 31, No. 12, November 1959, pp. B28-B33.

2. Dunning; H. N.; J. L. Eakin, and C. J. Walker. Using Foaming Agents To Remove Liquids From Gas Wells. BuMines and American Gas Association Monograph $11,1961,38 \mathrm{pp}$.

3. Dunning, H. N., J. B. Thielen, and D. L. Anderson. New Foaming Agents for Tough Gas-Wel1 Cleanout. $0 i 1$ and Gas J., v. 59, No. 49, Dec. 4, 1961, pp. 167-169.

4. Dunning, H. N., and C. J. Walker. Method For Remova1 of Liquid and Solid Materials From Gas-Well Bores. U.S. Pat. 3,073,387, Jan. 15, 1963.

5. Eakin, J. L., R. T. Johansen, A. D. Hopkins, and R. W. Taliaferro. How Chemical Treatment Gets Rid of Gas-We11 Water Blocks. Oil and Gas J., v. 60 , No. 48 , Nov. 26,1962, pp. $85-89$.

6. Eakin, J. L., J. S. Miller, and V. Vern Hutchison. A Review of Well Stimulation and Techniques to Prevent Formation Damage in Oil and Gas Production. BuMines Inf. Circ. 8235, 1964, 84 pp.

7. Johansen, R. T., H. N. Dunning, and Jeanne W. Beaty. Petroleum Displacement by Detergent Solutions. Producers Monthly, v. 20, No. 4, February 1956, pp. 26-35.

8. Johansen, R. T., J. P. Powe 11, and H. N. Dunning. The Use of Nonionic Detergent and Citric Acid for Improving Cleanout Procedures of WaterInput Wells in Secondary Oil-Recovery Projects. BuMines Inf. Circ. $7797,1957,38 \mathrm{pp}$.

9. Ra11, Cleo G., and Jack Wright. Analyses of Formation Brines in Kansas. BuMines Rept. of Inv. 4974, 1953, 40 pp.

10. Watkins, J. W. Properties of Produced Waters. Ch. 21 in Petroleum Production Handbook. McGraw-Hil1 Book Co., Inc., New York, 1962 , $20 \mathrm{pp}$.

11. Wright, Jack, Cynthia Pearson, Effie T. Kurt, and J. W. Watkins. Analyses of Brines From 0il-Productive Formations in Oklahoma. BuMines Rept. of Inv. 5326, 1957, 71 pp. 